\title{
OPEN Settlement of larvae from four families of corals in response to a crustose coralline alga and its biochemical morphogens
}

\author{
Taylor N. Whitman ${ }^{1,2}$, Andrew P. Negri ${ }^{1}{ }^{1}$, David G. Bourne ${ }^{\left({ }^{1,2}\right.}$ \& Carly J. Randall ${ }^{1}{ }^{\circledR}$
}

Healthy benthic substrates that induce coral larvae to settle are necessary for coral recovery. Yet, the biochemical cues required to induce coral settlement have not been identified for many taxa. Here we tested the ability of the crustose coralline alga (CCA) Porolithon onkodes to induce attachment and metamorphosis, collectively termed settlement, of larvae from 15 ecologically important coral species from the families Acroporidae, Merulinidae, Poritidae, and Diploastreidae. Live CCA fragments, ethanol extracts, and hot aqueous extracts of $P$. onkodes induced settlement (>10\%) for 11,7 , and 6 coral species, respectively. Live CCA fragments were the most effective inducer, achieving over $50 \%$ settlement for nine species. The strongest settlement responses were observed in Acropora spp.; the only non-acroporid species that settled over $50 \%$ were Diploastrea heliopora, Goniastrea retiformis, and Dipsastraea pallida. Larval settlement was reduced in treatments with chemical extracts compared with live CCA, although high settlement ( $>50 \%$ ) was reported for six acroporid species in response to ethanol extracts of CCA. All experimental treatments failed $(<10 \%)$ to induce settlement in Montipora aequituberculata, Mycedium elephantotus, and Porites cylindrica. Individual species responded heterogeneously to all treatments, suggesting that none of the cues represent a universal settlement inducer. These results challenge the commonly-held notion that CCA ubiquitously induces coral settlement, and emphasize the critical need to assess additional cues to identify natural settlement inducers for a broad range of coral taxa.

Corals represent the most important foundational species on tropical reef ecosystems; however, the world's coral populations are in decline due to increased anthropogenic disturbances ${ }^{1-4}$. The natural recovery of coral populations following a disturbance is largely dependent on the successful settlement and post-settlement survival of larvae from remaining coral colonies within local or nearby reef environments ${ }^{1,5-7}$. Yet, the increasing frequency and intensity of disturbances may no longer allow sufficient time for recovery between events ${ }^{8,9}$, and has lead to calls for direct rehabilitation interventions ${ }^{10-14}$ with sexually produced coral larvae ${ }^{11,15,16}$. Thus, identifying the cues, and particularly the biochemical inducers that underpin larval settlement, is an essential first step in manipulating the settlement of mass-cultured coral larvae onto natural or artificial substrates for deployment ${ }^{11,15,16}$.

The mobile, planktonic phase of the coral life cycle is the most dynamic, though paradoxically, the least understood. Planktonic coral larvae can survive for weeks to months $s^{17-19}$ but may lose settlement competency as they age and in the absence of appropriate cues from the environment ${ }^{20-25}$. For well-studied coral species such as the Caribbean agariciids and some Pacific acroporids, the evidence thus far indicates that coral larvae actively swim, crawl, and investigate reef surfaces using receptors to select their preferred settlement substrates ${ }^{5,26}$ such as crustose coralline algae (CCA) (e.g. Porolithon onkodes, Hydrolithon reinboldii, or Titanoderma prototypum ${ }^{21-23,27,28}$ ), crustose forms of red algae (e.g. Peyssonnelia spp. ${ }^{22,23}$ ), and their associated bacterial biofilms (e.g. Psuedoaltermonas spp. ${ }^{27,29-31}$ ). Studies suggest that once the preferred substrata have been identified, coral larvae may recognize subtle differences in morphogen concentrations, and use these signals to select an attachment site and activate metamorphosis into a sessile polyp ${ }^{21,23,27}$.

Labile chemical settlement inducers have been previously isolated from CCA species using alcohol (methanol or ethanol ${ }^{21,22}$ ) and hot water extractions $\mathrm{s}^{27,32}$, and by gentle decalcifications with chelators (e.g. ethylenediaminetetraacetic acid, EDTA ${ }^{23,32}$ ). The most potent biochemical morphogens identified to date include alcohol-soluble

\footnotetext{
${ }^{1}$ Australian Institute of Marine Science, PMB 3, Townsville, QLD 4810, Australia. ${ }^{2}$ College of Science and Engineering, James Cook University, 1 James Cook Drive, Townsville, QLD 4810, Australia. ${ }^{\boxplus}$ email: c.randall@ aims.gov.au
} 
www.nature.com/scientificreports/

\begin{tabular}{|c|c|c|c|c|c|c|}
\hline \multirow[t]{2}{*}{ Family } & \multirow[t]{2}{*}{ Species } & \multicolumn{4}{|c|}{ Settlement Inducer } & \multirow[t]{2}{*}{ Reference } \\
\hline & & Algal Species & Live fragment & Alcohol extract & Hot aqueous extract & \\
\hline \multirow[t]{55}{*}{ Acroporidae } & Acropora austera & Porolithon onkodes & ++ & ++ & - & This Study \\
\hline & \multirow[t]{4}{*}{ Acropora cervicornis } & Hyrdolithon boergesenii & + & $\mathrm{n} / \mathrm{a}$ & $\mathrm{n} / \mathrm{a}$ & \multirow[t]{4}{*}{30} \\
\hline & & Porolithon pachydermum & + & $\mathrm{n} / \mathrm{a}$ & $\mathrm{n} / \mathrm{a}$ & \\
\hline & & Paragoniolithon solubile & + & $\mathrm{n} / \mathrm{a}$ & $\mathrm{n} / \mathrm{a}$ & \\
\hline & & Titanoderma prototypum & + & $\mathrm{n} / \mathrm{a}$ & $\mathrm{n} / \mathrm{a}$ & \\
\hline & \multirow[t]{4}{*}{ Acropora digitifera } & Peyssonnelia sp. $\#$ & ++ & $\mathrm{n} / \mathrm{a}$ & $\mathrm{n} / \mathrm{a}$ & 23 \\
\hline & & Hydrolithon reinboldii & ++ & ++ & $\mathrm{n} / \mathrm{a}$ & 23,27 \\
\hline & & Porolithon onkodes & ++ & $\mathrm{n} / \mathrm{a}$ & $\mathrm{n} / \mathrm{a}$ & \multirow{2}{*}{27} \\
\hline & & Neogoniolithon fosliei & ++ & $\mathrm{n} / \mathrm{a}$ & $\mathrm{n} / \mathrm{a}$ & \\
\hline & \multirow[t]{2}{*}{ Acropora florida } & Peyssonnelia sp. ${ }^{\#}$ & ++ & $\mathrm{n} / \mathrm{a}$ & $\mathrm{n} / \mathrm{a}$ & \multirow[t]{2}{*}{23} \\
\hline & & Hydrolithon reinboldii & ++ & $\mathrm{n} / \mathrm{a}$ & $\mathrm{n} / \mathrm{a}$ & \\
\hline & \multirow[t]{2}{*}{ Acropora formosa } & Peyssonnelia sp. $\#$ & ++ & $\mathrm{n} / \mathrm{a}$ & $\mathrm{n} / \mathrm{a}$ & \multirow[t]{2}{*}{23} \\
\hline & & Hydrolithon reinboldii & ++ & ++ & $\mathrm{n} / \mathrm{a}$ & \\
\hline & \multirow[t]{2}{*}{ Acropora geinmifera } & Peyssonnelia sp. $\#$ & ++ & $\mathrm{n} / \mathrm{a}$ & $\mathrm{n} / \mathrm{a}$ & \multirow[t]{2}{*}{23} \\
\hline & & Hydrolithon reinboldii & ++ & ++ & $\mathrm{n} / \mathrm{a}$ & \\
\hline & \multirow{3}{*}{ Acropora globiceps } & Porolithon onkodes & ++ & $\mathrm{n} / \mathrm{a}$ & $\mathrm{n} / \mathrm{a}$ & \multirow[t]{3}{*}{27} \\
\hline & & Hydrolithon reinboldii & ++ & $\mathrm{n} / \mathrm{a}$ & $\mathrm{n} / \mathrm{a}$ & \\
\hline & & Neogoniolithon fosliei & ++ & $\mathrm{n} / \mathrm{a}$ & $\mathrm{n} / \mathrm{a}$ & \\
\hline & Acropora humulis & Porolithon onkodes & ++ & $\mathrm{n} / \mathrm{a}$ & $\mathrm{n} / \mathrm{a}$ & 27 \\
\hline & & Hydrolithon reinboldii & ++ & $\mathrm{n} / \mathrm{a}$ & $\mathrm{n} / \mathrm{a}$ & \\
\hline & & Neogoniolithon fosliei & ++ & $\mathrm{n} / \mathrm{a}$ & $\mathrm{n} / \mathrm{a}$ & \\
\hline & Acropora hyacinthus & Peyssonnelia sp. ${ }^{\#}$ & ++ & $\mathrm{n} / \mathrm{a}$ & $\mathrm{n} / \mathrm{a}$ & 23 \\
\hline & & Hydrolithon reinboldii & ++ & ++ & $\mathrm{n} / \mathrm{a}$ & \\
\hline & Acropora intermedia & Porolithon onkodes & ++ & $\mathrm{n} / \mathrm{a}$ & $\mathrm{n} / \mathrm{a}$ & 27 \\
\hline & & Hydrolithon reinboldii & ++ & $\mathrm{n} / \mathrm{a}$ & $\mathrm{n} / \mathrm{a}$ & \\
\hline & & Neogoniolithon fosliei & ++ & $\mathrm{n} / \mathrm{a}$ & $\mathrm{n} / \mathrm{a}$ & \\
\hline & Acropora longicyathus & Porolithon onkodes & ++ & ++ & + & This Study \\
\hline & Acropora loripes & Porolithon onkodes & ++ & ++ & ++ & This Study \\
\hline & Acropora millepora & Lithophyllum insipidum* & ++ & $\mathrm{n} / \mathrm{a}$ & $\mathrm{n} / \mathrm{a}$ & 22 \\
\hline & & Hydrolithon onkodes & ++ & $\mathrm{n} / \mathrm{a}$ & $\mathrm{n} / \mathrm{a}$ & $22,24,31$ \\
\hline & & $\begin{array}{l}\text { Neogoniolithon brassica- } \\
\text { florida }\end{array}$ & ++ & $\mathrm{n} / \mathrm{a}$ & $\mathrm{n} / \mathrm{a}$ & 22 \\
\hline & & Mesopyllum sp. & ++ & $\mathrm{n} / \mathrm{a}$ & $\mathrm{n} / \mathrm{a}$ & \\
\hline & & Peyssonnelia sp." & ++ & ++ & $\mathrm{n} / \mathrm{a}$ & \\
\hline & & Hydrolithon reinboldii & ++ & ++ & $\mathrm{n} / \mathrm{a}$ & 21 \\
\hline & & Neogoniolithon fosliei & ++ & ++ & $\mathrm{n} / \mathrm{a}$ & 21,31 \\
\hline & & Porolithon onkodes & ++ & ++ & ++ & $21,22,27$ \\
\hline & & & ++ & ++ & ++ & This Study \\
\hline & & Titanoderma prototypum & ++ & ++ & $\mathrm{n} / \mathrm{a}$ & 21 \\
\hline & & $\begin{array}{l}\text { Lithoporella } \\
\text { melobesioides }\end{array}$ & ++ & ++ & $\mathrm{n} / \mathrm{a}$ & \\
\hline & & $\begin{array}{l}\text { Titanoderma cf. } \\
\text { tessellatum }\end{array}$ & ++ & ++ & $\mathrm{n} / \mathrm{a}$ & 34 \\
\hline & Acropora micropthalma & Porolithon onkodes & ++ & ++ & - & This Study \\
\hline & Acropora muricata & Porolithon onkodes & ++ & ++ & ++ & This Study \\
\hline & Acropora nasuta & Peyssonnelia sp. ${ }^{\#}$ & ++ & $\mathrm{n} / \mathrm{a}$ & $\mathrm{n} / \mathrm{a}$ & 23 \\
\hline & & Hydrolithon reinboldii & + & + & na & \\
\hline & Acropora palifera & Peyssonnelia sp. & ++ & $\mathrm{n} / \mathrm{a}$ & $\mathrm{n} / \mathrm{a}$ & 50 \\
\hline & & Hydrolithon sp. & + & $\mathrm{n} / \mathrm{a}$ & $\mathrm{n} / \mathrm{a}$ & \\
\hline & & Porolithon sp. & + & $\mathrm{n} / \mathrm{a}$ & $\mathrm{n} / \mathrm{a}$ & \\
\hline & Acropora palmata & Hydrolithon boergesenii & ++ & $\mathrm{n} / \mathrm{a}$ & $\mathrm{n} / \mathrm{a}$ & 30 \\
\hline & & Porolithon pachydermum & + & $\mathrm{n} / \mathrm{a}$ & $\mathrm{n} / \mathrm{a}$ & \\
\hline & & Paragoniolithon solubile & + & $\mathrm{n} / \mathrm{a}$ & $\mathrm{n} / \mathrm{a}$ & \\
\hline & & Titanoderma prototypum & + & $\mathrm{n} / \mathrm{a}$ & $\mathrm{n} / \mathrm{a}$ & \\
\hline & Acropora surculosa & Porolithon onkodes & ++ & $\mathrm{n} / \mathrm{a}$ & $\mathrm{n} / \mathrm{a}$ & 27 \\
\hline & & Hydrolithon reinboldii & ++ & $\mathrm{n} / \mathrm{a}$ & $\mathrm{n} / \mathrm{a}$ & \\
\hline & & Neogoniolithon fosliei & ++ & $\mathrm{n} / \mathrm{a}$ & $\mathrm{n} / \mathrm{a}$ & \\
\hline & Acropora tenuis & Hydrolithon reinboldii & ++ & ++ & $\mathrm{n} / \mathrm{a}$ & 23,21 \\
\hline
\end{tabular}




\begin{tabular}{|c|c|c|c|c|c|c|}
\hline & & Neogoniolithon fosliei & ++ & $\mathrm{n} / \mathrm{a}$ & $\mathrm{n} / \mathrm{a}$ & 21 \\
\hline & & \multirow[t]{2}{*}{ Porolithon onkodes } & ++ & ++ & ++ & 21,27 \\
\hline & & & $\mathrm{n} / \mathrm{a}$ & ++ & ++ & This Study \\
\hline & & $\begin{array}{l}\text { Lithoporella } \\
\text { melobesioides }\end{array}$ & ++ & $\mathrm{n} / \mathrm{a}$ & $\mathrm{n} / \mathrm{a}$ & \multirow[t]{2}{*}{21} \\
\hline & & Titanoderma prototypum & ++ & $\mathrm{n} / \mathrm{a}$ & $\mathrm{n} / \mathrm{a}$ & \\
\hline & & Peyssonnelia sp. ${ }^{\#}$ & ++ & $\mathrm{n} / \mathrm{a}$ & $\mathrm{n} / \mathrm{a}$ & 23 \\
\hline & Acropora willisae & Lithophyllum sp. ${ }^{*}$ & ++ & $\mathrm{n} / \mathrm{a}$ & $\mathrm{n} / \mathrm{a}$ & 24 \\
\hline & Montipora aequituberculata & Porolithon onkodes & - & - & - & This Study \\
\hline & \multirow[t]{3}{*}{ Montipora hispida } & Porolithon onkodes & ++ & $\mathrm{n} / \mathrm{a}$ & $\mathrm{n} / \mathrm{a}$ & \multirow[t]{3}{*}{27} \\
\hline & & Hydrolithon reinboldii & ++ & $\mathrm{n} / \mathrm{a}$ & $\mathrm{n} / \mathrm{a}$ & \\
\hline & & Neogoniolithon fosliei & ++ & $\mathrm{n} / \mathrm{a}$ & $\mathrm{n} / \mathrm{a}$ & \\
\hline \multirow[t]{8}{*}{ Agariciidae } & \multirow[t]{2}{*}{ Agaricia agaricites } & Porolithon sp. & + & $\mathrm{n} / \mathrm{a}$ & - & \multirow[t]{2}{*}{28} \\
\hline & & unknown CCA sp. 1 & ++ & $\mathrm{n} / \mathrm{a}$ & ++ & \\
\hline & \multirow[t]{5}{*}{ Agaricia humilis } & Hydrolithon boergesenii & ++ & $\mathrm{n} / \mathrm{a}$ & ++ & 32,51 \\
\hline & & Porolithon pachydermum & - & $\mathrm{n} / \mathrm{a}$ & $\mathrm{n} / \mathrm{a}$ & \multirow[t]{2}{*}{32} \\
\hline & & $\begin{array}{l}\text { Neogoniolithon } \\
\text { megacarpum }\end{array}$ & - & $\mathrm{n} / \mathrm{a}$ & $\mathrm{n} / \mathrm{a}$ & \\
\hline & & Peyssonnelia sp. ${ }^{\#}$ & ++ & $\mathrm{n} / \mathrm{a}$ & $\mathrm{n} / \mathrm{a}$ & \multirow[t]{2}{*}{23} \\
\hline & & Hydrolithon reinboldii & ++ & $\mathrm{n} / \mathrm{a}$ & + & \\
\hline & Agaricia tenuifolia & Hyrdolithon boergesenii & ++ & $\mathrm{n} / \mathrm{a}$ & ++ & 32 \\
\hline \multirow[t]{13}{*}{ Merulinidae } & $\begin{array}{l}\text { Dipsastraea favus [Formerly } \\
\text { Favia] }\end{array}$ & Peyssonnelia sp. ${ }^{\#}$ & + & $\mathrm{n} / \mathrm{a}$ & $\mathrm{n} / \mathrm{a}$ & 23 \\
\hline & $\begin{array}{l}\text { Dipsastraea matthaii [Formerly } \\
\text { Favia] }\end{array}$ & Porolithon onkodes & + & - & - & This Study \\
\hline & \multirow{4}{*}{$\begin{array}{l}\text { Dipsastraea pallida }[\text { Formerly } \\
\text { Favia] }\end{array}$} & \multirow[t]{2}{*}{ Porolithon onkodes } & ++ & $\mathrm{n} / \mathrm{a}$ & $\mathrm{n} / \mathrm{a}$ & 27 \\
\hline & & & ++ & - & - & This Study \\
\hline & & Hydrolithon reinboldii & ++ & $\mathrm{n} / \mathrm{a}$ & $\mathrm{n} / \mathrm{a}$ & \multirow[t]{2}{*}{27} \\
\hline & & Neogoniolithon fosliei & ++ & $\mathrm{n} / \mathrm{a}$ & $\mathrm{n} / \mathrm{a}$ & \\
\hline & \multirow[t]{3}{*}{ Goniastrea retiformis } & Peyssonnelia sp. ${ }^{\#}$ & - & $\mathrm{n} / \mathrm{a}$ & $\mathrm{n} / \mathrm{a}$ & 23,52 \\
\hline & & Hydrolithon reinboldii & + & $\mathrm{n} / \mathrm{a}$ & $\mathrm{n} / \mathrm{a}$ & 52 \\
\hline & & Porolithon onkodes & ++ & - & + & This Study \\
\hline & \multirow[t]{2}{*}{ Cyphastrea sp. } & Hydrolithon reinboldii & + & + & $\mathrm{n} / \mathrm{a}$ & \multirow[t]{2}{*}{23} \\
\hline & & Peyssonnelia sp.\# & + & + & $\mathrm{n} / \mathrm{a}$ & \\
\hline & Mycedium elephantotus & Porolithon onkodes & - & - & - & This Study \\
\hline & Platygyra daedalea & Porolithon onkodes & + & - & - & This Study \\
\hline \multirow[t]{3}{*}{ Siderastreidae } & \multirow[t]{3}{*}{ Pseudosiderastrea tayamai } & Porolithon onkodes & ++ & $\mathrm{n} / \mathrm{a}$ & $\mathrm{n} / \mathrm{a}$ & \multirow[t]{3}{*}{27} \\
\hline & & Hydrolithon reinboldii & ++ & $\mathrm{n} / \mathrm{a}$ & $\mathrm{n} / \mathrm{a}$ & \\
\hline & & Neogoniolithon fosliei & ++ & $\mathrm{n} / \mathrm{a}$ & $\mathrm{n} / \mathrm{a}$ & \\
\hline \multirow[t]{3}{*}{ Poritidae } & \multirow[t]{2}{*}{ Stylaraea punctata } & Hydrolithon reinboldii & - & $\mathrm{n} / \mathrm{a}$ & $\mathrm{n} / \mathrm{a}$ & \multirow[t]{2}{*}{52} \\
\hline & & Peyssonnelia sp. ${ }^{\#}$ & - & $\mathrm{n} / \mathrm{a}$ & $\mathrm{n} / \mathrm{a}$ & \\
\hline & Porites cylindrica & Porolithon onkodes & - & - & - & This Study \\
\hline Pocilloporidae & Stylophora. pistillata & Porolithon sp. & + & $\mathrm{n} / \mathrm{a}$ & $\mathrm{n} / \mathrm{a}$ & 50 \\
\hline & & Peyssonnelia sp. ${ }^{\#}$ & + & $\mathrm{n} / \mathrm{a}$ & $\mathrm{n} / \mathrm{a}$ & \\
\hline & & Hydrolithon sp. & + & $\mathrm{n} / \mathrm{a}$ & $\mathrm{n} / \mathrm{a}$ & \\
\hline Dendrophylliidae & Tubastrea aurea & Hydrolithon boergesenii & - & - & $\mathrm{n} / \mathrm{a}$ & 32 \\
\hline Diploastreidae & Diploastrea heliopora & Porolithon onkodes & ++ & - & - & This Study \\
\hline No assigned & Leptastrea purpurea & Porolithon onkodes & ++ & $\mathrm{n} / \mathrm{a}$ & $\mathrm{n} / \mathrm{a}$ & 27 \\
\hline & & Hydrolithon reinboldii & ++ & $\mathrm{n} / \mathrm{a}$ & $\mathrm{n} / \mathrm{a}$ & \\
\hline & & Neogoniolithon fosliei & ++ & $\mathrm{n} / \mathrm{a}$ & $\mathrm{n} / \mathrm{a}$ & \\
\hline
\end{tabular}

Table 1. Summary of the species-specific responses to crustose red algal-associated settlement inducers reported previously and tested here. Algae include crustose coralline algae, branching coralline algae ${ }^{*}$ and crustose red algae". The "+" and "-" symbols and their associated colors represent the strength of the settlement response, where known: “++" > 50\% (green), “+” 10-50\% (yellow), “-"<10\% (red). n/a indicates treatments that were not tested. Refer to Table 2 for complete results of this study.

monoacylated glycoglycerolipids ${ }^{27}$ and material that can be released with hot water extractions from the algal tissue or calcified cell wall (e.g. large molecular weight polysaccharides ${ }^{27}$ ). These morphogens have been shown to induce $>80 \%$ settlement for Acropora millepora, Agaricia humilis, and Agaricia tenuifolia ${ }^{27,32}$ (Table 1). Biochemicals such as the metabolite tetrabromopyrrole (TBP) extracted from a Pseudoalteromonas sp. bacterium associated with the surface of the CCA species Neogoniolithon fosliei and Hydrolithon onkodes have also induced settlement of Acropora millepora ${ }^{31}$, Acropora palmata, Orbicella franksi, and Porites astreoides ${ }^{33}$. However, while larval metamorphosis was achieved in response to TBP for many Indo-Pacific coral species ${ }^{27}$, low rates of attachment $(<50 \%)$ were observed, and complete attachment only occurred when the larvae were exposed to secondary cues (e.g. live CCA $)^{27}$. Thus, inconsistent larval attachment in response to TBP, combined with the scarcity of TBP, calls into question its ecological relevance and suggests that the primary settlement inducer for Acropora spp. may be a component of the CCA itself ${ }^{27}$.

The biochemical cues required for larval settlement have yet to be identified for many coral taxa, and there is an urgent need to find reliable techniques to settle a diversity of coral species for restoration activities ${ }^{16}$. Therefore, the objectives of this study were two-fold. We first undertook an extensive review of the literature to summarize known coral larval settlement cues in response to crustose red algae (Table 1), which revealed the abundant shallow-water CCA species, Porolithon onkodes, to be a broad settlement inducer ${ }^{21,35}$. We then tested 


\begin{tabular}{|c|c|c|c|c|c|c|c|}
\hline \multirow[b]{2}{*}{ Family } & \multirow[b]{2}{*}{ Species } & \multicolumn{6}{|c|}{ Settlement Inducer } \\
\hline & & FSW & $\mathrm{CCA}$ & $\begin{array}{c}\text { EtOH } \\
\text { extract }\end{array}$ & $\begin{array}{c}\text { Hot } \\
\text { aqueous } \\
\text { extract }\end{array}$ & $\begin{array}{c}\text { Large } \\
\text { molecule } \\
\text { extract }\end{array}$ & $\begin{array}{c}\text { Small } \\
\text { molecule } \\
\text { extract }\end{array}$ \\
\hline \multirow[t]{8}{*}{ Acroporidae } & Acropora loripes & - & $++^{*}$ & $++^{*}$ & $++^{*}$ & $++^{*}$ & + ns \\
\hline & Acropora millepora & - & $++{ }^{*}$ & $++^{*}$ & $++^{*}$ & $+{ }^{*}$ & $+{ }^{*}$ \\
\hline & Acropora muricata & - & $++{ }^{*}$ & $++{ }^{*}$ & $++^{*}$ & - & $+{ }^{*}$ \\
\hline & Acropora longicyathus & - & $++^{*}$ & $++^{*}$ & $+^{*}$ & $\mathrm{n} / \mathrm{a}$ & $\mathrm{n} / \mathrm{a}$ \\
\hline & Acropora tenuis & - & $\mathrm{n} / \mathrm{a}$ & $++^{*}$ & $++^{*}$ & $+{ }^{*}$ & - \\
\hline & Acropora austera & - & $++{ }^{*}$ & $++^{*}$ & - & - & - \\
\hline & Acropora micropthalma & - & $++^{*}$ & $++^{*}$ & - & - & - \\
\hline & Montipora aequituberculata & - & - & - & - & $\mathrm{n} / \mathrm{a}$ & $\mathrm{n} / \mathrm{a}$ \\
\hline \multirow[t]{5}{*}{ Merulinidae } & Goniastrea retiformis & - & $++^{*}$ & - & $+^{*}$ & - & - \\
\hline & Platygyra daedalea & - & $+{ }^{*}$ & - & - & $\mathrm{n} / \mathrm{a}$ & $\mathrm{n} / \mathrm{a}$ \\
\hline & Mycedium elephantotus & - & - & - & - & - & - \\
\hline & Dipsastraea pallida [Formerly Favia] & - & $++^{*}$ & - & - & - & - \\
\hline & Dipsastraea matthaii [Formerly Favia] & - & $+^{*}$ & - & - & - & - \\
\hline Poritidae & Porites cylindrica & - & - & - & - & $\mathrm{n} / \mathrm{a}$ & $\mathrm{n} / \mathrm{a}$ \\
\hline Diploastreidae & Diploastrea heliopora & - & $++^{*}$ & - & - & - & - \\
\hline
\end{tabular}

Table 2. Summary of species-specific coral settlement responses to each experimental inducer with live or extracted Porolithon onkodes. Symbols and their associated colours represent average percent settlement categories: "++" > 50\% (green), "+" 10-50\% (yellow), "-" < 10\% (red). n/a indicates treatments that were not tested. ${ }^{*}$ A statistically significant difference $(\mathrm{p}<0.05)$ in percent larval settlement compared with FSW negative controls (Kruskal-Willis one-way ANOVA on ranks with pairwise Wilcox test). $n s$ indicates not significant. See Supplementary Tables S1 and S2 for more details.

the inductive ability of $P$. onkodes and its associated ethanol and hot aqueous-derived biochemicals to induce the settlement of 15 broadcast spawning coral species from the families Acroporidae, Merulinidae, Poritidae, and Diploastreidae. Biochemical extracts were further refined by size fractionation, to disentangle the potential role of large and small-molecular weight polysaccharides ${ }^{27}$ in cuing coral settlement. Experiments were run using controlled larval settlement assays and the treatments included (1) filtered seawater (FSW; negative control), (2) live P. onkodes (CCA) fragments ( $25 \mathrm{~mm}^{2}$; positive control), (3) ethanol extracts, and (4) hot aqueous extracts of P. onkodes, fractionated into two molecular size classes $(<$ and $>100 \mathrm{kDa})$. Our aims were to determine whether CCA-associated cues can be used to induce coral settlement across taxa and to identify which chemical constituents of CCA (ethanol or hot-water soluble) contain the most potent settlement inducers.

\section{Results and discussion}

Settlement in response to crustose coralline algal cues. Larvae of all coral species required a cue to settle, with $<10 \%$ settlement recorded in negative controls (Table 2). The experimental Porolithon onkodes cues (live fragments, ethanol extracts, and hot aqueous extracts) induced settlement $(>10 \%)$ in 11,7 , and 6 coral species, respectively (Table 2). On average, species within the genus Acropora were the most responsive to all the experimental cues, and they settled best on live CCA and with ethanol extracts. The only non-acroporids that settled well (>50\%) in response to live P. onkodes were Diploastrea heliopora, Goniastrea retiformis, and Dipsastraea pallida (Table 2). All experimental cues failed ( $<10 \%)$ to induce settlement of Montipora aequitburculata, Mycedium elephantotus, and Porites cylindrica larvae (Table 2), indicating that none of the cues tested represent a universal settlement inducer.

Species-specific responses to live CCA fragments. Live P. onkodes fragments were the most effective larval settlement inducers across taxa, achieving $>50 \%$ settlement in 9 of the 14 experimental species tested (Table 2, Fig. 1, Supplementary Table S1). The highest larval settlement (mean \pm SE) was identified for A. loripes $(100 \pm 0 \%)$, while strongly responsive corals from other families included D. heliopora $(95 \pm 3 \%)$, G. retiformis $(76 \pm 8 \%)$, and D. pallida (73 $\pm 10 \%)$ (Fig. 1; Supplementary Table S1). In contrast, live P. onkodes failed to induce settlement in Montipora, Mycedium, and Porites (Table 2).

CCA fragments inducted high settlement (on average between 59 and 100\%) across the seven Acropora spp. tested (Fig. 1; Supplementary Table S1). This result is consistent with previous studies (Table 1) and indicates 


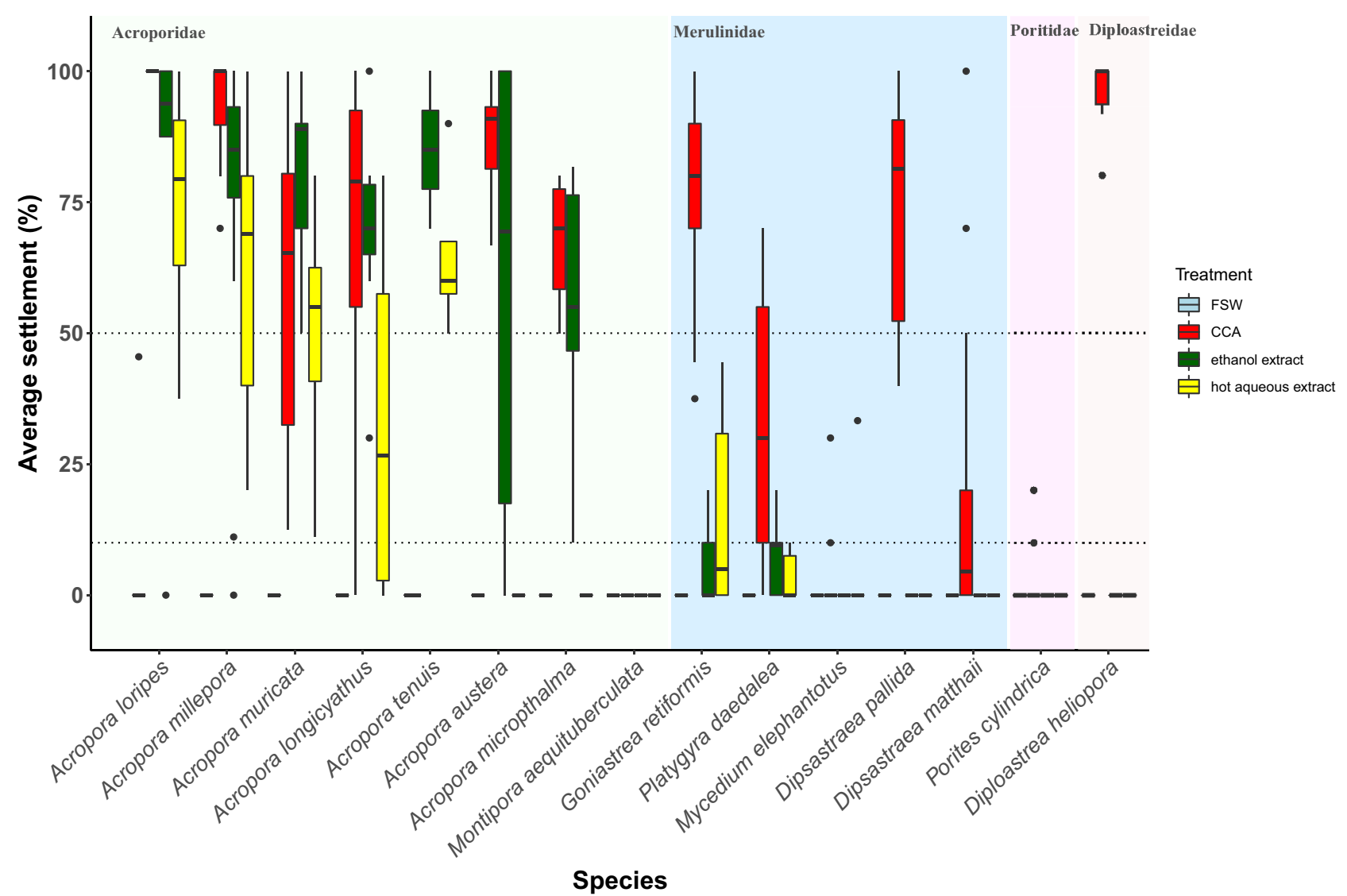

Figure 1. Larval settlement (\%) for each coral species across four experimental treatments: (1) filtered seawater (FSW), (2) live Porolithon onkodes CCA fragment, (3) ethanol extract, and (4) hot aqueous extract of P. onkodes. Box plots identify the median and interquartile range of settlement; whiskers are 1.5 times the interquartile range and outlying points are identified. Background shading identifies the family to which each species belongs. Dotted horizontal lines at 10 and 50\% represent theoretical thresholds for low and high settlement, respectively. Between 4 and 16 replicate wells per treatment were tested in each assay. We note that the CCA treatment was not tested for Acropora tenuis

that Acropora spp. may be more responsive to P. onkodes-associated cues during settlement than other genera. Indeed, a wide diversity of CCA species, as well as some crustose red algae (non-coralline e.g. Peyssonnelia spp.) and branching coralline algae (e.g. Lithophyllum spp.) have been shown to induce settlement in Acropora spp. (Table 1), indicating that this response is likely to be ecologically important and potentially useful for restoration efforts with this genus. However, specific CCA surface chemistry, which is likely to differ among algal species, is expected to play an influential role in determining the settlement preferences of each coral species ${ }^{21,27,34}$.

The lack of settlement by Montipora aequituberculata in response to live CCA was surprising given that this species is within the family Acroporidae and because Montipora spp. can be found in environments amongst CCA such as $P$. onkodes ${ }^{35,36}$. Yet, $M$. aequituberculata is not dominant on the reef crest where $P$. onkodes thrives ${ }^{35}$, whereas many of the Acropora species tested are common in that environment. Similarly, Mycedium and Porites are more common on reef slopes under lower light conditions ${ }^{37}$, and in back reef environments ${ }^{38,39}$, respectively, which may explain their lack of responsiveness to $P$. onkodes. Previous literature has reported high settlement ( $>50 \%$ ) in other Montipora species in response to P. onkodes (Table 1). Thus, future research should increase taxonomic replication to obtain a broader sense of settlement preferences across Monitpora taxa. While Acropora larvae (and those of some other families) responded strongly to P. onkodes, the CCA fragments tested in this study were not treated with antibiotics, heat or pressure, so we cannot discount the possibility that CCA-associated bacterial communities may contribute to settlement induction ${ }^{24,29,31,33,34}$.

Larval preference for CCA extracts derived with ethanol. The ethanol extract was the most potent chemical cue tested, inducing $>50 \%$ settlement for seven species, respectively, with the highest settlement in $A$. muricata ( $82 \pm 4 \%$; Fig. 1; Supplementary Table S1). However, only species within the genus Acropora responded $(>10 \%)$ to ethanol extracts, and in most cases the response to live CCA was stronger (Fig. 1; Supplementary Table S1). Only two non-acroporids, $P$. daedalea $(7 \pm 2 \%)$ and $G$. retiformis $(5 \pm 2 \%)$, demonstrated any settlement response to the ethanol extract (Fig. 1; Supplementary Table S1), though both species responded more strongly to live CCA. This result, along with the reduction or absence of settlement in extract treatments com- 


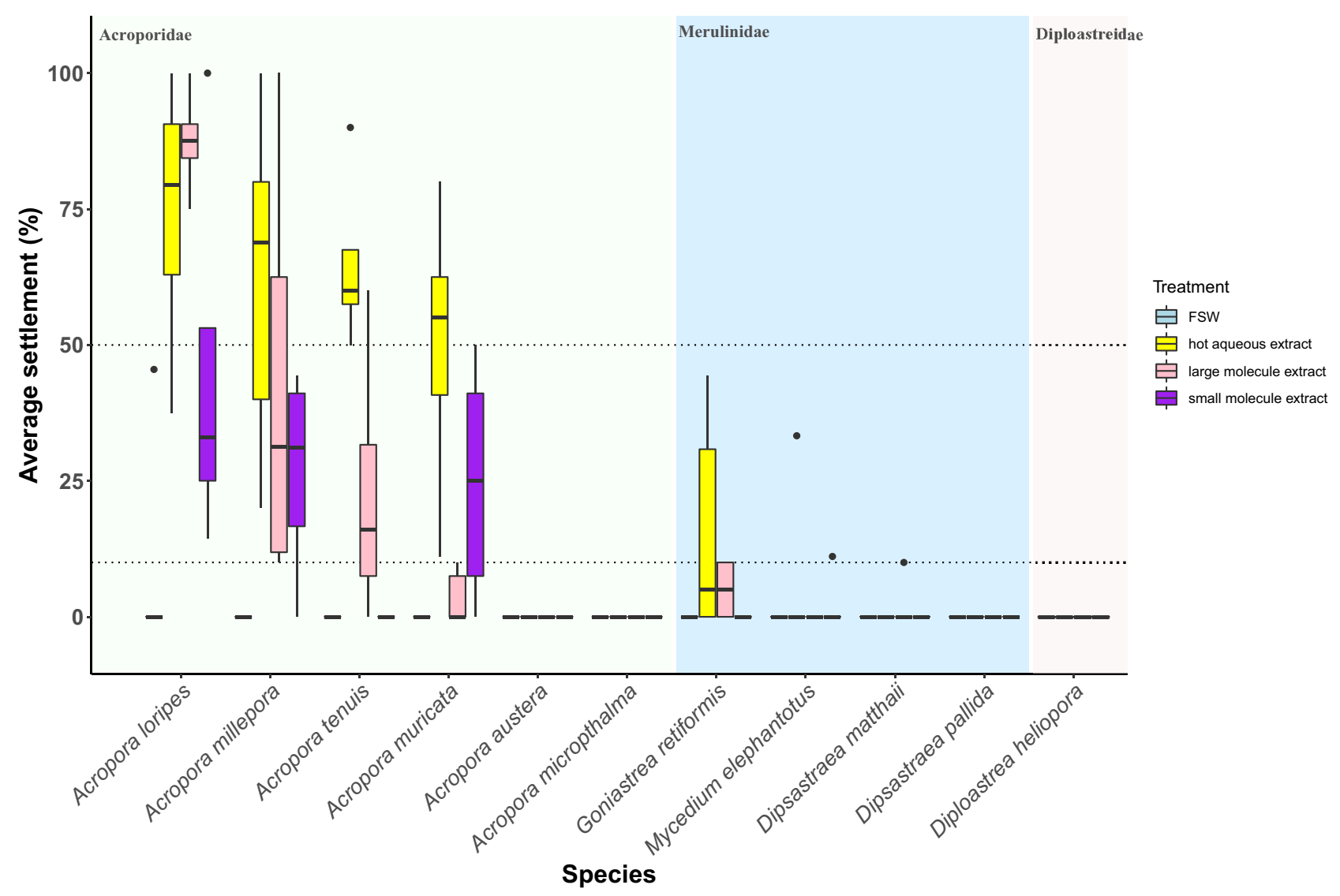

Figure 2. Larval settlement (\%) in response to three hot aqueous extracts of Porolithon onkodes: (1) crude hot aqueous extract, (2) large molecular weight extract (>100 kDa), and (3) small molecular weight extract $(<100 \mathrm{kDa})$. Box plots identify the median and interquartile range of settlement; whiskers are 1.5 times the interquartile range and outlying points are identified. Background shading identifies the family to which each species belongs. Only species that spawned in November 2018 were used in settlement trials with sizefractionated hot aqueous extracts. Dotted horizontal lines at 10 and 50\% represent theoretical thresholds for low and high settlement, respectively. Between 4 and 15 replicate wells per treatment were tested in each assay. See Table 3 for more details.

pared with live CCA treatments generally, suggests that the cues required to complete metamorphosis and settlement likely extend beyond the small, bioactive organic compounds released from the CCA thallus ${ }^{21,22,27,40}$.

Similar studies investigating the role of alcohol-derived CCA and coral rubble extracts containing the macrodiolide luminaolide reported up to $90 \%$ settlement in Leptastrea purpurea ${ }^{41}$. However, the ecological significance of luminaolide is uncertain as its source (a mixture of CCA and rubble) and abundance on the substrate are unknown ${ }^{41}$. It is also likely that this compound is produced by microalgal or bacterial communities ${ }^{41}$, which highlights the need to chemically characterize isolates to identify the complete composition of inductive extracts and explore alternative sources of cues that may be linked to coral settlement in situ. Since the concentrations of ethanol extract used in this experiment were selected based on preliminary trials with A. millepora larvae only (Supplementary Fig. S1), we also emphasize the need to develop dose-response curves for all experimental species, which may help to explain individual responses to species-specific morphogens, such as those observed for Indo-Pacific Acropora spp. ${ }^{21}$ and the Caribbean species Agaricia agaricites ${ }^{28}$ to chemical derivatives of different CCA species (Table 1). Indeed, optimising species-specific doses would be required if ethanol-derived chemicals were used for the settlement of coral propagules en masse, for reef restoration.

Settlement induction by hot aqueous and size fractionated CCA extracts. The crude hot aqueous extract induced settlement $(>10 \%)$ for six species and was a strong inducer $(>50 \%)$ for A. lorpies, A. millepora, A. muricata, and A. tenuis (Fig. 2; Supplementary Table S1). A. loripes exhibited the strongest response to this cue $(74 \pm 14 \%)$. All Acropora spp. induced by the crude hot aqueous extract were also induced $(>10 \%)$ by extracts separated by molecular size, although fractionated extracts were the least inductive treatments tested (Table 2, Fig. 2). Low to no settlement was observed in several species in response to size-fractionated extracts, and greater than $50 \%$ settlement was only reported for A. loripes in treatments with the large molecule extract (Table 2, Fig. 2). This result, along with previous reports of high settlement induction for A. millepora by this cue $^{27}$ (Table 1), suggests that water soluble large molecular weight polysaccharides may act as an effective settlement inducer for some Acropora spp. corals. However, there are still discrepancies that exist surrounding the 


\begin{tabular}{|c|c|c|c|c|c|c|}
\hline Family & Species & Spawning date & No. spawning colonies & Collection location & Spawning time & Reproductive mode \\
\hline \multirow{9}{*}{ Acroporidae } & Acropora austera & 28-Nov-18 & 5 & Davies and Backnumbers reefs & $19: 58$ & Hermaphroditic \\
\hline & Acropora longicyathus & $31-$ Oct-18 & 6 & Palm Islands & $19: 05$ & Hermaphroditic \\
\hline & Acropora loripes & 28-Nov-18 & 6 & $\begin{array}{l}\text { Davies reef, but captive for years } \\
\text { at AIMS }\end{array}$ & $19: 40$ & Hermaphroditic \\
\hline & Acropora micropthalma & 28-Nov-18 & 3 & Davies and Backnumbers reefs & $20: 26$ & Hermaphroditic \\
\hline & \multirow{2}{*}{ Acropora millepora } & $28-$ Oct-18 & 7 & Palm Islands & $20: 40$ & Hermaphroditic \\
\hline & & 1-Dec-18 & 7 & Davies and Backnumbers reefs & $21: 10$ & Hermaphroditic \\
\hline & Acropora muricata & 27-Nov-18 & 5 & Davies and Backnumbers reefs & $21: 16-21: 40$ & Hermaphroditic \\
\hline & Acropora tenuis & 28-Nov-18 & 7 & Davies and Backnumbers reefs & $19: 25$ & Hermaphroditic \\
\hline & Montipora aequituberculata & $31-$ Oct-18 & 4 & Palm Islands & $20: 00$ & Hermaphroditic \\
\hline Diploastreidae & Diploastrea heliopora & 27-Nov-18 & $5(3 \precsim, 2 q)$ & Davies and Backnumbers reefs & $22: 55-23: 15$ & Gonochoric \\
\hline \multirow{6}{*}{ Merulinidae } & \multirow{2}{*}{ Goniastrea retiformis } & 29-Oct-18 & 9 & Palm Islands & $20: 50$ & Hermaphroditic \\
\hline & & 27-Nov-18 & 5 & Davies and Backnumbers reefs & $20: 35$ & Hermaphroditic \\
\hline & Mycedium elephantotus & 28-Nov-18 & 4 & Davies and Backnumbers reefs & $21: 06$ & Hermaphroditic \\
\hline & Platygyra daedalea & 28 -Oct-18 & 13 & Palm Islands & $18: 45$ & Hermaphroditic \\
\hline & $\begin{array}{l}\text { Dipsastraea matthaii [Formerly } \\
\text { Favia] }\end{array}$ & 28-Nov-18 & 3 & Davies and Backnumbers reefs & $21: 20$ & Hermaphroditic \\
\hline & Dipsastraea pallida [Formerly Favia] & 28-Nov-18 & 3 & Davies and Backnumbers reefs & $23: 35$ & Hermaphroditic \\
\hline Poritidae & Porites cylindrica & 28 -Oct-18 & $2(1 \hat{\jmath}, 1$ \&) & Palm Islands & $21: 05$ & Gonochoric \\
\hline
\end{tabular}

Table 3. Spawning information for each coral species that was tested in the larval settlement assays in October and November 2018. Symbols $\hat{\delta}$ and $q$ represent male and female coral colonies, respectively. Full moons were on 25th October at 02:45 and 23rd November at 15:39.

settlement of $A$. millepora in response to large molecular weight extracts, such as the $<50 \%$ settlement observed in our study compared with to the $>90 \%$ settlement reported by Tebben et al. ${ }^{27}$.

It is unclear why size fractionation usually resulted in the loss of activity in both the large and small fractions. It could be that compounds were lost on the filter or that molecules of differing sizes work synergistically to induce settlement and without one or the other, the effect is lessened. Moreover, the small molecular weight extract $(<100 \mathrm{kDa})$ in our study induced $>10 \%$ settlement in three species (including A. millepora), highlighting an interesting and unexpected result since Tebben et al. ${ }^{27}$ reported no settlement of $A$. millepora in response to this cue. The variability in these responses could be caused by a number of factors related to either or both the state of the coral larvae and the CCA, or minor differences in the extraction and separation methods. These discrepancies support the need for further detailed studies before applying these cues in restoration activities. While hot aqueous extracts were less inductive than ethanol extracts, this extraction technique and decalcification method $^{23,32}$ should be further explored for other CCA and coral species combinations, and across a range of concentrations.

\section{Conclusions}

This study provides a critical assessment of settlement cues derived from the CCA Porolithon onkodes for several species of ecologically important reef-building corals, a pressing issue to progress the rehabilitation of reefs which are under pressure from global climate change ${ }^{16}$. While our findings confirm the role of CCA in inducing settlement and metamorphosis in Acropora spp. and some other species (i.e. Diploastrea heliopora, Goniastrea retiformis, and Dipsastraea pallida), we also found that alcohol or water-soluble morphogens from this CCA may be unimportant for settlement of corals outside Acropora. For many coral species there may well be multiple cues acting in concert to induce settlement ${ }^{34}$, and these cues are potentially constructed from multi-domain microbial communities associated with inductive reef substrata ${ }^{29,42-44}$ that may interact with physical factors such as surface rugosity ${ }^{25}$. The declines in settlement observed following the removal of the surface texture associated with live CCA fragments, as well as the decline observed with increasing refinement of the chemical cues tested in this study, support this hypothesis. The effects of microbial biofilms on settlement induction highlights an important future research priority for less-studied coral families such as Poritidae and Merulinidae. Research should incorporate chemically (antibiotics, organic solvents) and physically (heat and pressure) treated natural substrates to determine if epiphytic bacteria on live or dead fragments of CCA or reef rubble induce coral settlement. As the natural recovery of coral populations is impeded by a rapidly changing climate, the identification of the cues responsible for the recruitment of a diversity of coral species is urgently needed.

\section{Materials and methods}

Coral collection and spawning. Coral colonies were collected from the central Great Barrier Reef (GBR) prior to the 2018 October and November spawning events (Table 3) and transported to outdoor, flowthrough seawater aquaria (average light intensity $74 \mu \mathrm{mol}$ photons $\mathrm{m}^{-1} \mathrm{~s}^{-1}$ and temperature $27-28{ }^{\circ} \mathrm{C}$ ) within the National Sea Simulator (SeaSim) at the Australian Institute of Marine Science (AIMS, Townsville, Queensland). The timing of spawning and the numbers of colonies that contributed to mass cultures are reported in Table 3. 
Gamete bundles were collected, separated, washed, and fertilized as described in Pollock et al. ${ }^{45}$, except for the gonochoric species Diploastrea heliopora and Porites cylindrica; for these species, male and female colonies were placed together in a stagnant temporary holding tank until they spawned. After spawning, the adult colonies were removed from the tank and the gametes were allowed to fertilize for $\sim 1 \mathrm{~h}$. Embryos were then transferred to larval rearing tanks (either 75 or $500 \mathrm{l}$ ), at a stocking density of $\sim 0.5-1$ larva $\mathrm{ml}^{-1}$. Culture tanks received flowthrough $0.4 \mu \mathrm{m}$ filtered seawater (FSW) at $27.0-27.5^{\circ} \mathrm{C}$ and gentle aeration beginning $\sim 16 \mathrm{~h}$ post fertilization. Larvae remained in rearing tanks and once they reached settlement competency as determined by daily laboratory assays, they were tested in the experiment.

Cue preparation. Fragments of the widely distributed and ecologically significant crustose coralline alga (CCA) Porolithon onkodes ${ }^{35}$ were collected in October and November 2018 (Backnumbers Reef, GBR, Australia, $\left.18^{\circ} 30^{\prime} 22^{\prime \prime} \mathrm{S}, 147^{\circ} 8^{\prime} 47^{\prime \prime} \mathrm{E}\right)$ from the shallow reef flat $(<6 \mathrm{~m})$ by hammer and chisel, and were transferred to the SeaSim where they were maintained in outdoor holding tanks prior to use in controlled larval settlement trials. Fragments of $P$. onkodes were cut $\left(\sim 25 \mathrm{~mm}^{2}\right)$ and distributed across replicate wells for the live CCA treatment or were processed further for extraction. Each fragment contained an upper surface characterized by a live tissue layer over a thin $(\sim 2 \mathrm{~mm})$ calcium carbonate skeletal layer. When possible, a continuous piece of CCA was cut into fragments and used in settlement trials over multiple timepoints to minimize variation in the CCA used in the assays. Several large pieces of CCA were cut into fragments for chemical extractions. All CCA fragments were maintained under stable culture conditions to minimize any temporal changes in their inductive abilities, and only healthy-appearing fragments, with normal coloration and surface texture, were used in the assays.

To prepare extractions, CCA fragments $\left(25 \mathrm{~mm}^{2}\right)$ were ground by mortar and pestle and then transferred to a $500 \mathrm{ml}$ Schott bottle until $100 \mathrm{~g}$ of crushed material was obtained. $150 \mathrm{ml}$ of $100 \%$ absolute ethanol (EtOH) was added to the material and the paste was mixed horizontally on a roller for $2 \mathrm{~h}$ at room temperature. The liquid ethanol extract was then decanted and stored $\left(-20^{\circ} \mathrm{C}\right.$ ) and the CCA paste was re-extracted with EtOH (overnight on a roller) to remove additional $\mathrm{EtOH}$-soluble material. The $\mathrm{EtOH}$ extracts were combined, concentrated under vacuum, filtered (Whatman GF/F, $0.7 \mu \mathrm{m}$ ) and then prepared in $10 \%$ concentrations with EtOH (concentration equivalent to $0.5 \mathrm{~g} \mathrm{CCA} \mathrm{ml}^{-1}$ ).

The remaining EtOH-extracted CCA paste (100 g) was resuspended twice in $150 \mathrm{ml}$ Milli-Q (MQ) water, mixed thoroughly, centrifuged $(1000 \times g)$ and then the supernatant was discarded to remove salts. The rinsed CCA paste was placed in a loosely capped $250 \mathrm{ml}$ Schott Duran bottle with $100 \mathrm{ml} \mathrm{MQ}$ water and autoclaved for $1 \mathrm{~h}$ $\left(121^{\circ} \mathrm{C}\right.$ and $\left.15 \mathrm{psi}\right)$. This process was repeated until $200 \mathrm{ml}$ of crude hot aqueous extract was collected, filtered (Whatman GF/F, $0.7 \mu \mathrm{m}$ ), and concentrated under vacuum (final concentration equivalent to $0.5 \mathrm{~g} \mathrm{CCA} \mathrm{ml}^{-1}$ ). $12 \mathrm{ml}$ of crude hot aqueous extract was then centrifuged $(40 \mathrm{~min}$ at $15,000 \times \mathrm{g})$ using $100 \mathrm{kDa}$ molecular weight cut-off filters (VS0141, Sartorius) to separate the extract by molecular size. Filter residue was washed $2 \times$ by resuspending in EtOH:water (9:1) followed by centrifugation (20 min at 15,000 $\times g$ ). Liquid containing low molecular weight compounds that passed through the filter membrane were combined. The remaining filter residue was resuspended in $12 \mathrm{ml}$ of EtOH:water (9:1) and homogenized (Soniclean Ultrasonic) for $2 \mathrm{~h}$ at room temperature. The pooled aqueous filtrate containing small molecules only $(<100 \mathrm{kDa})$, and the homogenized filter residue containing large molecules only $(>100 \mathrm{kDa})$, were then concentrated under vacuum overnight (Savant Universal SpeedVac Vacuum System, Thermo Scientific), resuspended in $12 \mathrm{ml}$ of MQ water, and stored $\left(-20^{\circ} \mathrm{C}\right)$ until use. All methods for hot aqueous extraction of CCA (crude, large molecule, and small molecule) were modified from Tebben et al. ${ }^{27}$.

Settlement assays. Larval settlement assays were performed in sterile 6-well cell-culture plates maintained in a constant-temperature room $\left(27-28^{\circ} \mathrm{C}\right)$ under a $12: 12 \mathrm{~h} \mathrm{light:dark} \mathrm{cycle}\left(\sim 20 \mu \mathrm{mol}\right.$ photons $\left.\mathrm{m}^{-2} \mathrm{~s}^{-1}\right)$. Coral larvae $(n=10)$ were transferred by pipette into each well containing the cue to be tested along with FSW to a final volume of $10 \mathrm{ml}$. Assays included up to six treatments: (1) negative FSW control; (2) live P. onkodes fragment ( $\left.25 \mathrm{~mm}^{2}\right)$; (3) ethanol CCA extract; (4) hot aqueous (crude) CCA extract; (5) small molecular weight hot aqueous extract; and (6) large molecular weight hot aqueous extract. Between 4 and 16 replicate wells per treatment were tested in each assay. The volumes applied were based on the results of range-finding tests (between 0 and $15 \mu \mathrm{l}$ ) with Acropora millepora ("Supplementary Methods" and Fig. S1), which identified $5 \mu \mathrm{l}$ (final well concentration of $12.5 \mu \mathrm{g} \mathrm{CCA} \mathrm{ml}{ }^{-1}$ ) of ethanol extract as the most effective volume. All hot aqueous extracts were applied in three volumes $\left(10,30\right.$, and $100 \mu \mathrm{l}$ for a final well concentration of 25,75 and $250 \mu \mathrm{g} \mathrm{CCA} \mathrm{ml} \mathrm{m}^{-1}$, respectively; Supplementary Fig. S2). The small and large molecular weight hot aqueous extracts were only used in settlement assays with 11 species, while treatments 1-4 were applied to all species (Supplementary Table S1).

Settlement assays with treatments 1-3 (FSW, live CCA, and ethanol extract) included six replicates and were run daily for one week, then every second day for 2 more weeks. Assays with hot aqueous extracts (treatments 4-6), included 2-4 replicate wells per volume, and were tested over 1-4 time points. All larvae were tested between 10 and 31 days old, and within their competency windows ${ }^{17-19}$ (Supplementary Table S1). Each assay was set-up with a new cohort of larvae, and all assays were assessed after $24 \mathrm{~h}$. No water changes were performed during the $24 \mathrm{~h}$ settlement period. Settlement was scored by direct counting of all larvae and newly settled polyps in each well using a standard dissecting microscope. Larvae were defined as settled if they had firmly attached to the substrate and exhibited pronounced flattening of the oral-aboral axis with obvious septal mesenteries radiating from the central mouth (i.e. metamorphosed ${ }^{22}$ ).

Data analysis. Comparisons of settlement patterns were only made between the treatments and the negative control, since the study specifically aimed to identify potential inducers for coral settlement, and because the results of range-finding tests (Supplementary Figs. S1 and S2) were not species specific and thus not opti- 
mized. For hot aqueous extract treatments, the sample concentration yielding the highest settlement response (either $10 \mu \mathrm{l}, 30 \mu \mathrm{l}$, or $100 \mu \mathrm{l}$ ), was chosen for the statistical assessment for each species (Supplementary Fig. S2). Where possible, data were analysed by non-parametric Kruskal-Wallis one-way ANOVA on ranks followed by pairwise comparisons (Wilcox test), since the conditions of normality and homoscedasticity could not be met or improved by transformation and where this was not possible, the data were qualitatively compared. Statistical analyses were run and the data were visualized using R statistical software ${ }^{46}$ with the 'dplyr ' ${ }^{\text {'47 }}$, 'tidyverse ${ }^{38}$, and 'ggplot2'49 packages; see Supplementary Tables S1 and S2 for more detailed information).

Received: 21 April 2020; Accepted: 11 September 2020

Published online: 02 October 2020

\section{References}

1. De'ath, G. et al. The 27-year decline of coral cover on the Great Barrier Reef and its causes. Proc. Natl. Acad. Sci. USA 109, 17995-17999 (2012).

2. Hughes, T. P. et al. Global warming and recurrent mass bleaching of corals. Nature 546, 82-90 (2017).

3. Pandolfi, J. M. et al. Global trajectories of the long-term decline of coral reef ecosystems. Science 301, 955-958 (2003).

4. Wilkinson, C. R. \& Souter, D. N. Status of Caribbean Coral Reefs After Bleaching and Hurricanes in 2005 Vol. 148 (Global Coral Reef Monitoring Network and Reef and Rainforest Research Center, Townsville, 2008).

5. Harrison, P. L. \& Wallace, C. C. Reproduction, dispersal and recruitment of scleractinian corals. In Ecosystems of the world: coral reefs 133-207 (Elsevier, Amsterdam, The Netherlands, 1990).

6. Jones, R., Ricardo, G. \& Negri, A. Effects of sediments on the reproductive cycle of corals. Mar. Pollut. Bull. 100, 13-33 (2015).

7. Nozawa, Y. \& Harrison, P. L. Larval settlement patterns, dispersal potential, and the effect of temperature on settlement of larvae of the reef coral, Platygyra daedalea, from the Great Barrier Reef. Proc. Int. Coral Reef Symp. 1, 409-416 (2000).

8. Hughes, T. P. et al. Global warming transforms coral reef assemblages. Nature 556, 492-496 (2018).

9. Ortiz, J. C. et al. Impaired recovery of the Great Barrier Reef under cumulative stress. Sci. Adv. 4, eaar6127. https://doi.org/10. 1126/sciadv.aar6127 (2018).

10. Guest, J. R. et al. Rearing coral larvae for reef rehabilitation. In Reef Rehabilitation Manual (ed. Edwards, A.) 73-98 (Coral Reef Targeted Research \& Capacity Building for Management Program, St. Lucia, Australia, 2010).

11. Guest, J. et al. Closing the circle: Is it feasible to rehabilitate reefs with sexually propagated corals?. Coral Reefs 33, 45-55 (2014).

12. Rinkevich, B. Conservation of coral reefs through active restoration measures: Recent approaches and last decade progress. Environ. Sci. Technol. 39, 4333-4342 (2005).

13. Van Oppen, M. J. et al. Shifting paradigms in restoration of the world's coral reefs. Glob. Change Biol. 23, 3437-3448 (2017).

14. Anthony, K. et al. New interventions are needed to save coral reefs. Nat. Ecol. Evol. 1, 1420-1422 (2017).

15. Edwards, A. J. et al. Direct seeding of mass-cultured coral larvae is not an effective option for reef rehabilitation. Mar. Ecol. Prog. Ser. 525, 105-116 (2015).

16. Randall, C. J. et al. Sexual production of corals for reef restoration in the Anthropocene. Mar. Ecol. Prog. Ser. 635, 203-232 (2020).

17. Graham, E. M., Baird, A. H. \& Connolly, S. R. Survival dynamics of scleractinian coral larvae and implications for dispersal. Coral Reefs 27, 529-539 (2008).

18. Connolly, S. R. \& Baird, A. H. Estimating dispersal potential for marine larvae: dynamic models applied to scleractinian corals. Ecology 91, 3572-3583 (2010).

19. Figueiredo, J., Baird, A. H. \& Connolly, S. R. Synthesizing larval competence dynamics and reef-scale retention reveals a high potential for self-recruitment in corals. Ecology 94, 650-659 (2013).

20. Fiechter, J. et al. Physical processes impacting passive particle dispersal in the Upper Florida Keys. Cont. Shelf Res. 28, 1261-1272 (2008).

21. Harrington, L. et al. Recognition and selection of settlement substrata determine post-settlement survival in corals. Ecology 85, 3428-3437 (2004).

22. Heyward, A. \& Negri, A. Natural inducers for coral larval metamorphosis. Coral Reefs 18, 273-279 (1999).

23. Morse, A. N. et al. An ancient chemosensory mechanism brings new life to coral reefs. Biol. Bull. 191, 149-154 (1996).

24. Negri, A. et al. Metamorphosis of broadcast spawning corals in response to bacteria isolated from crustose algae. Mar. Ecol. Prog. Ser. 223, 121-131 (2001).

25. Whalan, S. et al. Larval settlement: The role of surface topography for sessile coral reef invertebrates. PLoS ONE 10, e0117675. https://doi.org/10.1371/journal.pone.0117675 (2015).

26. Fadlallah, Y. H. Sexual reproduction, development and larval biology in scleractinian corals. Coral Reefs 2, 129-150 (1983).

27. Tebben, J. et al. Chemical mediation of coral larval settlement by crustose coralline algae. Sci. Rep. 5, 10803. https://doi.org/10. 1038/srep10803 (2015).

28. Morse, D. E. et al. Control of larval metamorphosis and recruitment in sympatric agariciid corals. J. Exp. Mar. Biol. Ecol. 116, 193-217 (1988).

29. Webster, N. S. et al. Metamorphosis of a scleractinian coral in response to microbial biofilms. Appl. Environ. Microbiol. 70, 1213-1221 (2004).

30. Ritson-Williams, R. et al. Larval settlement preferences and post-settlement survival of the threatened Caribbean corals Acropora palmata and A. cervicornis. Coral Reefs 29, 71-81 (2009).

31. Tebben, J. et al. Induction of larval metamorphosis of the coral Acropora millepora by tetrabromopyrrole isolated from a Pseudoalteromonas bacterium. PLoS ONE 6, e19082. https://doi.org/10.1371/journal.pone.0019082 (2011).

32. Morse, D. E. \& Morse, A. N. Enzymatic characterization of the morphogen recognized by Agaricia humilis (scleractinian coral) larvae. Biol. Bull. 181, 104-122 (1991).

33. Sneed, J. M. et al. The chemical cue tetrabromopyrrole from a biofilm bacterium induces settlement of multiple Caribbean corals. Proc. Roy. Soc. B-Biol. Sci. 281, 20133086. https://doi.org/10.1098/rspb.2013.3086 (2014).

34. Gómez-Lemos, L. A. et al. Coralline algal metabolites induce settlement and mediate the inductive effect of epiphytic microbes on coral larvae. Sci. Rep. 8, 17557. https://doi.org/10.1038/s41598-018-35206-9 (2018).

35. Maneveldt, G. W. \& Keats, D. W. Taxonomic review based on new data of the reef-building alga Porolithon onkodes (Corallinaceae, Corallinales, Rhodophyta) along with other taxa found to be conspecific. Phytotaxa. 190, 216-249 (2014).

36. Gouezo, M. et al. Relative roles of biological and physical processes influencing coral recruitment during the lag phase of reef community recovery. Sci. Rep. 10, 2471. https://doi.org/10.1038/s41598-020-59111-2 (2020).

37. Baird, A. \& Bridges, T. Mycedium elephantotus. Coral Trait Database Consortium. https://coraltraits.org/species/1070 (2020).

38. Baird, A. \& Bridges, T. Porites cylindrica. Coral Trait Database Consortium. https://coraltraits.org/species/1281 (2020). 
39. Smith, L. W. \& Birkeland, C. Effects of intermittent flow and irradiance level on back reef Porites corals at elevated seawater temperatures. J. Exp. Mar. Biol. Ecol. 341, 282-294 (2007).

40. Hadfield, M. G. \& Paul, V. J. Natural chemical cues for settlement and metamorphosis of marine invertebrate larvae. Mar. Chem. Ecol. 13, 431-461 (2001).

41. Kitamura, M. et al. Luminaolide, a novel metamorphosis-enhancing macrodiolide for scleractinian coral larvae from crustose coralline algae. Tetrahedron Lett. 50, 6606-6609 (2009).

42. Ritson-Williams, R., Arnold, S. N. \& Paul, V. J. Patterns of larval settlement preferences and post-settlement survival for seven Caribbean corals. Mar. Ecol. Prog. Ser. 548, 127-138 (2016).

43. Sharp, K. et al. Induction of larval settlement in the reef coral Porites astreoides by a cultivated marine Roseobacter strain. Biol. Bull. 228, 98-107 (2015).

44. Shikuma, N. J. et al. Marine tubeworm metamorphosis induced by arrays of bacterial phage tail-like structures. Science 343, 529-533 (2014).

45. Pollock, F. J. et al. Coral larvae for restoration and research: A large-scale method for rearing Acropora millepora larvae, inducing settlement, and establishing symbiosis. PeerJ. 5, e3732. https://doi.org/10.7717/peerj.3732 (2017).

46. R Core Team. R: Language and environment for statistical computing.(R Foundation for Statistical Computing, 2019).

47. Wickham, H., Francois, R., Henry L. \& Muller, K. dplyr: A Grammar of Data Manipulation. R package version 0.8.0.1. https:// CRAN.R-project.org/package=dplyr (2019).

48. Wickham, H. et al. Welcome to the Tidyverse. J. Open Source Soft. 4, 16860. https://doi.org/10.21105/joss.01686 (2019).

49. Wickham, H. ggplot2: Elegant Graphics for Data Analysis (Springer, New York, 2016).

50. Baird, A. H. \& Morse, A. N. Induction of metamorphosis in larvae of the brooding corals Acropora palifera and Stylophora pistillata. Mar. Freshw. Res. 55, 469-472 (2004).

51. Raimondi, P. T. \& Morse, A. N. The consequences of complex larval behavior in a coral. Ecology 81, 3193-3211 (2000).

52. Golbuu, Y. \& Richmond, R. H. Substratum preferences in planula larvae of two species of scleractinian corals, Goniastrea retiformis and Stylaraea punctata. Mar. Biol. 152, 639-644 (2007).

\section{Acknowledgements}

Coral and algal collections were completed under permit \# G12/35236.1 issued by the Great Barrier Reef Marine Park Authority to the Australian Institute of Marine Science. Funding for this research was provided by the Australian Institute of Marine Science (AIMS), James Cook University, and AIMS@JCU Student Pilot Research Award to T. Whitman. Coral collection and larval rearing facilities were provided by AIMS National Sea Simulator facility and staff. Thanks to Christine Giuliano, Briony Stephenson, Jennifer Grossmann, and Justin Speaks for project support and data collection.

\section{Author contributions}

T.N.W. conceptualized and coordinated the study, with guidance provided by C.J.R. and A.P.N.; T.N.W. performed the analyses, and prepared figures/tables; C.J.R., A.P.N. and D.G.B. supervised the project and contributed to manuscript preparation. All authors approved final draft.

\section{Competing interests}

The authors declare no competing interests.

\section{Additional information}

Supplementary information is available for this paper at https://doi.org/10.1038/s41598-020-73103-2.

Correspondence and requests for materials should be addressed to C.J.R.

Reprints and permissions information is available at www.nature.com/reprints.

Publisher's note Springer Nature remains neutral with regard to jurisdictional claims in published maps and institutional affiliations.

(c) (i) Open Access This article is licensed under a Creative Commons Attribution 4.0 International License, which permits use, sharing, adaptation, distribution and reproduction in any medium or format, as long as you give appropriate credit to the original author(s) and the source, provide a link to the Creative Commons licence, and indicate if changes were made. The images or other third party material in this article are included in the article's Creative Commons licence, unless indicated otherwise in a credit line to the material. If material is not included in the article's Creative Commons licence and your intended use is not permitted by statutory regulation or exceeds the permitted use, you will need to obtain permission directly from the copyright holder. To view a copy of this licence, visit http://creativecommons.org/licenses/by/4.0/.

(c) Crown 2022 